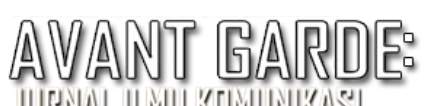

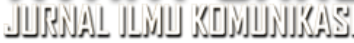 \\ Urip Mulyadi' Mubarok \\ Universitas Islam Sultan Agung \\ Jalan Raya Kaligawe KM.4, Semarang \\ oeripmulia@unissula.ac.id,mubarok@unissula.ac.id
}

\title{
Konstruksi Media Terhadap Berita Awal Munculnya Covid-19 di Indonesia (Analisis Framing Pada Berita Detik.com dan Kompas.com)
}

Submitted: 21 Januari 2021, Revised: 29 September 2021, Accepted: 10 Oktober 2021

\begin{abstract}
Abstrak
Diumumkannya kasus Covid-19 pertama kali di Indonesia secara langsung oleh Presiden Jokowi telah membuat kehebohan di masyarakat. Karena sebagian besar informasi yang beredar di media sosial sumbernya berasal dari media online atau portal berita online. Peran media dalam wabah seperti ini sama pentingnya dengan dokter dan tenaga medis, karena biasanya isu kesehatan di Indonesia jarang menjadi primadona. Penelitian ini bertujuan untuk mengetahui bagaimana pembingkaian atau framing Detik.com dan Kompas.com mengenai wabah COVID-19 di Indonesia. Metode yang digunakan dalam penelitian ini adalah analisis isi teks media dengan analisis data melalui model Model Pan dan Kosicki pendekatan paradigma konstruktivisme melalui metode penelitian kualitatif. Hasil penelitian menunjukkan bahwa Detik.com dan Kompas.com melakukan fungsi media sebagai kontrol sosial dengan pembingkaian yang sama dalam menanggapi situasi kepanikan di tengah masyarakat setelah Presiden Jokowi mengumumkan dua WNI pertama yang positif Covid-19 di Indonesia. Secara garis besar pembingkaian berita yang dilakukan oleh kedua media online ini memiliki tema yang sama dalam menginformasikan upaya-upaya menghadapi pandemi dengan tenang, menggerakkan pola hidup sehat, tidak panic buying dan mengantisipasi kemungkinan terburuk.
\end{abstract}

Kata Kunci : Analisis framing, Covid-19, Media Online, Kontrol Sosial

\section{Media Construction of Early News Emergence Covid-19 in Indonesia (Framing Analysis on Detik.com and Kompas.com News)}

\begin{abstract}
Covid-19 announcement of the case the first time in Indonesia directly by the President Jokowi has made people panic. Because most of the information circulating on social media comes from online media. The role of the media in a pandemic is as important as doctors and medical personnel, because usually health issues in Indonesia are rarely a concern. This study aims to determine how Detik.com and Kompas.com framing about the COVID-19 outbreak in Indonesia. The method used in this research is the analysis of media text context with data analysis through the Pan and Kosicky framing model using the constructivism paradigm through qualitative research methods. The results showed that Detik.com and Kompas.com perform media functions as a social control with the same framing in response to a situation of panic in the community after President Jokowi announced two positive first citizen Covid-19 in Indonesia. In general, the framing of the news carried out by the two online media has the same theme in informing efforts to deal with the pandemic calmly, moving a healthy lifestyle, not panic buying and anticipating the worst.
\end{abstract}

Keywords: framing analysis, Covid-19, online media, social control 


\section{PENDAHULUAN}

Senin, 2 Maret 2020 untuk pertama kalinya dua warga Negara Indonesia terinfeksi Covid-19. Pengumuman itu disampaikan secara langsung oleh Presiden Jokowi di Istana Kepresidenan bersama Menteri Kesehatan Terawan Agus Putranto. Dalam definisinya Virus Corona merupakan keluarga besar virus yang dapat menginfeksi unggas dan mamalia termasuk kepada manusia. World Health Organisation (WHO) menyebut bahwa virus ini menyebabkan penyakit menular mulai dari influenza ringan hingga infeksi saluran pernapasan yang lebih parah seperti MERS-CoV dan SARS-CoV. Virus ini bersifat zoonosis, artinya ia merupakan penyakit yang dapat ditularkan antara hewan dan manusia. Dikutip dari merdeka.com sejarah virus ini cukup Panjang, Dalam 70 tahun terakhir, para ilmuwan telah menemukan bahwa virus ini dapat menginfeksi berbagai hewan diantaranya anjing, tikus , kalkun, babi, kuda dan hewan ternak lainnya. Kadang-kadang hewan tersebut dapat menularkan virus corona kepada manusia. Virus corona $(\mathrm{CoV})$ memiliki peran yang besar terhadap beberapa wabah di seluruh dunia, termasuk saat pandemi SARS tahun 2002 - 2003 dan wabah MERS (Middle East Respiratory Syndrome) di Korea Selatan tahun 2015. Sejak Desember 2019, virus corona ini mulai muncul di Cina tepatnya di kota Wuhan yangmana disebut sebagai Covid-19, kemudian merebak di beberapa negara sehingga WHO mendeklarasikannya sebagai pandemi global (Mardatila, 2020).

Nama virus ini diambil dari bahasa latin yang berarti mahkota, karena virus ini berbentuk seperti paku yang menonjol menyerupai mahkota. Pada tahun 1937, para ilmuwan untuk pertama kalinya mengisolasi virus ini karena menyebabkan penyakit bronkitis menular pada hewan ternak atau unggas. kemudian tahun 1965, peneliti bernama Tyrell dan Bynoe menemukan adanya infeksi virus Corona pada manusia yang sedang flu, dengan melalui kultur organ trakea embrionik didapat pada saluran pernapasan penderita flu tersebut.

Penyebaran virus ini terbilang cepat dan meluas, bahkan menurut situs www.worldometer.info sudah terdapat 198 Negara yang terkena dampak Covid-19. Dengan total jumlah kasus per 2 Maret 2020 adalah sebanyak 88.232 kasus, 3000 angka kematian, 42.000 angka kesembuhan. Di Indonesia virus ini juga mengalami kenaikan yang cukup signifikan, dikutip dari situs remi milik pemerintah pusat www.covid19.go.id data jumlah kasus per 28 Maret 2020 atau 26 hari sejak kasus pertama adalah sebanyak 1047 kasus, 46 dinyatakan sembuh dan 87 meninggal. Hingga pertengahan januari 2021 sudah terdapat 858.043 kasus terkonfirmasi dan 24.951 kasus meninggal di Indonesia (covid19.go.id, 2020).

Corona telah membawa dampak bukan pada kesehatan saja, melainkan juga memberi dampak pada kehidupan social dan ekonomi. Bahkan di era Internet of Things (IoT) seperti ini Berbagai pihak juga turut membagikan informasi terkait Covid-19 ini melalui platform media sosial. Informasi tersebut bisa didapat dari kutipan ahli, pesan berantai, bahkan dari media online. Derasnya arus informasi dan perbincangan publik di media sosial terbukti dengan kata 'virus Corona" atau "Covid-19" yang seringkalo menempati kata populer di media sosial. Bahkan dengan derasnya arus informasi ini telah membuat kehebohan di masyarakat.

Selain pandemi Covid-19 yang dapat menewaskan orang, justru dengan banyaknya informasi membuat seseorang menjadi tak terkendali. Itulah yang dinamakan infodemik, yakni ledakan informasi yang menjadikan sebuah peristiwa tidak pasti. Bahkan, menurut 
laporan dari Menteri Komunikasi dan Informatika RI Johny G Plate per Desember 2020 terdapat 1.197 temuan isu hoax Covid-19 yang tersebar pada empat platform digital sejumlah 2020 sebaran, di Facebook 1497, di Instagram 20, di Twitter 482 dan di Youtube 21 kali. Yang sudah di-takedown atau diblokir sebanyak 1759. di Facebook sejumlah 1300, Instagram 15, Twitter 424 dan Youtube sejumlah 20 (Putri, 2020).

Selain media sosial, media online turut berperan dalam hal ini. Karena sebagian besar informasi yang beredar di media sosial sumbernya berasal dari media online atau portal berita online. Hingga tahun 2019, menurut Ketua Dewan Pers Yosep Adi Prasetyo jumlah media massa di Indonesia diperkirakan telah mencapai 47 ribu, terdiri dari 43.300 media online, 2000 media cetak, 674 radio, 523 televisi. Hampir 79 persen merupakan bukan media yang kredibel atau abal-abal dengan berita yang tidak bisa dipertanggungjawabkan. Dari ribuan media online tersebut, yang telah terverifikasi oleh Dewan Pers tidak lebih dari 100 media. Akibatnya, masyarakat sering terpapar dengan berita yang tidak benar atau hoax (Setiawan, 2020).

Peran media dalam wabah seperti ini sangat penting, sama halnya dengan dokter dan tenaga kesehatan. karena biasanya isu kesehatan di Indonesia jarang menjadi primadona. Sebuah penelitian menunjukkan bahwa peliputan Covid-19 ini lebih masif dibanding dengan virus Ebola. Tingginya intensitas peliputan Covid-19 ini disebabkan karena proses perjangkitannya yang cepat dan menelan banyak korban atau penderita.

Lima besar media online yang memiliki pengunjung terbanyak diantaranya Okezone.com, Tribunnews.com, Kompas.com, Detik.com, dan Pikiran-rakyat.com (Alexa.com, 2020). Kebijakan media dalam menentukan berita yang tepat untuk dipublikasikan juga memiliki kontribusi dalam membentuk opini publik. Media dapat mengarahkan hal-hal apa saja yang pantas menjadi perhatian khalayak. Jurnalistik online juga tidak mengenal deadline yang kita kenal di media cetak. Deadline dalam jurnalistik online dikatakan "publikasi paling lambat" adalah "beberapa menit bahkan detik" setelah peristiwa terjadi. Jurnalistik online juga dicirikan sebagai praktek jurnalistik yang memperhatikan berbagai platoform media (multimedia) dalam menyusun isi liputan membuat terjadinya hubungan timbal balik antara jurnalis dengan khalayak dan mengaitkan berbagai elemen berita dengan sumber online yang lainnya (Romli dalam Hutami \& Sjafirah, 2018).

Media online memiliki kelebihan dibandingkan media massa lainnya. Pemberitaan pada era digital saat ini, semakin terlihat melalui media online salah satu diantarannya adalah jurnalistik online. Bahkan media konvensional membuat media online tetap menyampaikan pemberitaan sebuah peristiwa dengan cepat dan ringan untuk diakses, bisa diperbarui dan bisa di-delete kapanpun, serta terdapat interaktifitas dengan pembaca (Hutami \& Sjafirah, 2018). Sebagai salah satu media online terbesar dan menempati posisi teratas di Indonesia, Detik.com dan Kompas.com juga memberitakan persoalan tersebut. Terlebih saat Presiden Jokowi mengumumkan untuk pertama kalinya ada dua WNI yang terinfeksi Covid-19, suasana di tengah masyarakat menjadi panik dan terjadi aksi panic buying. Narasi pemberitaan yang terkadang dilakukan secara berlebihan menjadikan alasan kuat terjadinya konflik dan ketegangan bagi masyarakat Indonesia. Maka dari itu dalam situasi seperti ini fungsi pers sebagai media kontrol sosial sesuai dengan amanat pasal 33 UU No. 40 Tahun 
1999 tentang pers untuk mengontrol, mengoreksi, mengkritik sesuatu yang bersifat konstruktif atau tidak membangun harus diutamakan (Komisi Informasi, 2018).

Melalui situs Detik.com dan Kompas.com saat awal peneliti berusaha melihat bingkai yang dipergunakan oleh kedua media, sehingga dapat dilihat kecenderungan pada penekanan masing-masing media karena peristiwa yang dimaknai secara berbeda-beda, dengan narasumber yang berbeda, dengan mengambil pusat perhatian yang berbeda pula. Bagi kaum konstruksionis, realitas bersifat subyektif, karena fakta atau peristriwa merupakan hasil konstruksi. Realitas tersebut hadir karena dihadirkan oleh pemikiran subyektif wartawan. Realitas tercipta melalui konstruksi dan pandangan tertentu. realitas dapat berbeda-beda, tergantung pada konsepsi ketika realitas tersebut dipahami oleh wartawan yang memiliki pandangan berbeda (Herbert J. Gans dalam Eriyanto, 2012). secara umum, pembingkaian terjadi karena adanya seleksi dan penekanan pada aspek-aspek realitas lewat beberapa cara seperti penempatan, pengulangan, implikasi terhadap karakter budaya, generalisasi, simplifikasi dan sebagainya. Tujuannya untuk menunjukkan aspek-aspek tertentu dari realitas yang diwacanakan menjadi tampak, dipahami dan impresif untuk khalayak (Rizki \& Junaedi, 2021).

Untuk dapat mengetahui bagaimana Detik.com dan Kompas.com membingkai pemberitaan tentang informasi mengenai Covid-19 setelah Presiden Jokowi mengumumkan dua WNI terkonfirmasi positif Covid-19 untuk pertama kalinya di Indonesia menggunakan model analisis Framing Zhongdang Pan dan Gerald M. Kosicki yang mana model ini dibagi menjadi 4 struktur, yakni struktur sintaksis, skrip, tematik dan koherensi, struktur retoris atau penggunaan kata idiom, gambar dan grafik.

\section{METODE PENELITIAN}

Jenis penelitian yang digunakan adalah penelitian kualitatif. Sifat penelitian ini adalah deksriptif analisis isi teks media dengan pendekatan paradigma konstruksionisme. Teknik pengumpulan datanya dengan melakukan dokumentasi pada pemberitaan tentang informasi mengenai Covid-19 setelah Presiden Jokowi mengumumkan dua WNI terkonfirmasi positif Covid-19 untuk pertama kalinya di Indonesia di Detik.com dan Kompas.com yang dipilih menggunakan teknik purposive sampling pada tanggal 2-3 Maret 2020.

Dalam penelitian ini teknik analisis data peneliti menggunakan analisis framing Zhongdang Pan dan Gerald M. Kosicki, model ini memiliki asumsi bahwa setiap pemberitaan memiliki pembingkaian yang berfungsi sebagai titik atau pusat pengorganisasian ide. Bingkai atau frami ini merupakan sebuah ide yang memiliki hubungan dengan elemen yang berbeda dalam teks berita, diantaranya seperti kutipan sumber, latar informasi, penggunaan kata atau kalimat tertentu ke dalam teks secara menyeluruh (Eriyanto,2012). 
Tabel 1 Model Framing Pan dan Kosicki (Eriyanto, 2012)

\begin{tabular}{|c|c|c|}
\hline Struktur & Perangkat Framing & Unit yang diamati \\
\hline $\begin{array}{l}\text { SINTAKSIS } \\
\text { Cara wartawan menyusun fakta }\end{array}$ & 1. Skema berita & $\begin{array}{l}\text { Headline, latar informasi, kutipan, sumber, } \\
\text { pernyataan, penutup }\end{array}$ \\
\hline $\begin{array}{l}\text { SKRIP } \\
\text { Cara Wartawan mengisahkan fakta }\end{array}$ & $\begin{array}{l}\text { 2. Kelengkapan } \\
\text { Berita }\end{array}$ & $5 \mathrm{~W}+1 \mathrm{H}$ \\
\hline $\begin{array}{l}\text { TEMATIK } \\
\text { Cara wartawan menekankan fakta }\end{array}$ & $\begin{array}{l}\text { 3. Detail } \\
\text { 4. Maksud kalimat, } \\
\text { hubungan } \\
\text { 5. Noralisasi antara } \\
\text { kalimat } \\
\text { 6. Koherensi } \\
\text { 7. Bentuk kalimat } \\
\text { 8. Kata ganti }\end{array}$ & Paragraf, proposisi \\
\hline $\begin{array}{l}\text { RETORIS } \\
\text { Cara wartawan menekankan fakta }\end{array}$ & $\begin{array}{l}\text { 9. Leksikon } \\
\text { 10. Grafis } \\
\text { 11. Metafor } \\
\text { 12. Pengandaian }\end{array}$ & Kata, idiom, gambar/foto, grafik \\
\hline
\end{tabular}

\section{HASIL DAN PEMBAHASAN}

Pada penelitian ini, peneliti menganalisis 5 berita dari Detik.com dan 5 berita dari Kompas.com yang fokus membahas mengenai respon media menanggapi situasi kepanikan di tengah masyarakat setelah Presiden Jokowi mengabarkan dua WNI pertama yang positif Covid-19 di Indonesia. Berikut 5 daftar berita dari Detik.com yang diteliti peneliti dengan judul "Menkes: Tak Perlu Fobia, Gerakan Hidup Sehat Cukup Cegah Corona", "Istana Minta Warga Tak Timbun Barang terkait Corona", "Ridwan Kamil: Jangan Panik Beli MaskerSembako, Supply Demand Kita Aman", "Rumah WNI Positif Corona di Depok Digaris Polisi, Kemenkes: Berlebihan" dan "Masker Diborong Usai WNI Terkena Corona, Awas Penimbun Bisa Dibui 5 Tahun!". Kemudian 5 daftar berita dari Kompas.com dengan judul "Ini Jurus Tangkal Virus Corona ala Ganjar Pranowo", "Masyarakat Diimbau Tak Timbun Masker dan Hand Sanitizer, Polisi Akan Bertindak Tegas", "Asosiasi Peritel Minta Masyarakat Tak Lakukan Aksi Borong Barang karena Ada Virus Corona", "Dua WNI Positif Corona, Khofifah Minta Jangan Buat Warga Jatim Galau", "Corona di Indonesia, Ketua Umum PMI Kalla Minta Jangan Panik dan Lakukan Hal". Semua berita tersebut terbit pada tanggal 2 Maret atau di hari yang sama saat Presiden Jokowi mengumumkan dua WNI terinfeksi Covid-19. Peneliti melihat dari empat struktur menurut Zhongdang Pan dan Kosicki sebagai berikut:

\section{Hasil Analisis Framing Detik.com}

Pertama, Struktur Sintaksis, peneliti melihat dari struktur ini bahwa judul yang dibuat oleh Detik.com berupaya untuk menciptakan rasa ketenangan di tengah masyarakat. Detik.com telah me-labeli artikelnya dengan judul-judul yang bisa mengontrol kondusifitas 
masyarakat, yang mana setelah Presiden Jokowi mengkonfirmasi dua orang Indonesia terjangkit Covid-19 terjadi kepanikan yang berlebih dan pada akhirnya terjadi panic buying.

Kemudian, lead yang digunakan Detik.com rata-rata adalah summary lead yang merupakan lead berita yang menyimpulkan dan dipadatkan. Masing-masing artikel lebih menonjolkan pada tokoh penting yang bisa diperhatikan oleh masyarakat terkait pernyataan mereka menanggapi positifnya dua WNI.

Kutipan-kutipan yang ditulis pun juga sejalan dengan judul yang dibuat, tokoh penting dalam hal ini adalah pejabat publik memberikan pernyataan-pernyataan untuk memberikan rasa tenang di masyarakat, misal kutipan pernyataan dari Menteri Kesehatan (Menkes) Terawan Agus Putranto soal pola hidup sehat bahwa kita harus menyesuaikan gerakan masyarakat hidup sehat (Germas) yang dirasa sudah sangat cukup untuk mencegah virus Corona ini menyebar. Kemudian Gubernur Jawa Barat Ridwan Kamil, Gubernur DKI Jakarta Anies Baswedan, Sekretaris Ditjen P2P Kemenkes Achmad Yurianto yang beberapa waktu lalu juga menjadi Juru Bicara Gugus Tugas Percepatan Penanganan Covid-19, dan Kepala Staf Kepresidenan Moeldoko.

Kedua, Struktur skrip, dilihat dari unsur kelengkapan penggunaan $5 \mathrm{~W}+1 \mathrm{H}$ dalam masing-masing berita terlihat lengkap dengan penekanan pada unsur What, Why dan How. Misal pada artikel yang berjudul "Ridwan Kamil: Jangan Panik Beli Masker-Sembako, Supply Demand Kita Aman” dengan unsur what menerangkan Gubernur Jawa Barat Ridwan Kamil (RK) mengimbau warga agar tidak panik menyikapi dua WNI positif virus Corona. Unsur Why yang menjelaskan Karena peristiwa kepanikan warga usai menyikapi dua warga negara Indonesia (WNI) positif virus Corona. Dan unsur How yang menjelaskan bagaimana pernyataan Gubernur Jawa Barat Ridwan Kamil tentang kepanikan itu berawal dari pembelian masker dan sembako yang berlebihan oleh masyarakat.

Ketiga, Struktur Tematik, dalam berita Detik.com teks ditulis dalam 5-7 paragraf dalam satu artikel, sebagian besar paragraf merupakan kutipan atau pernyataan langsung dari narasumber untuk mendukung tema artikel. Pernyataan dari perwakilan istana atau Pemerintah Pusat misal Menteri Kesehatan Terawan Agus Putranto, Kepala Staf Kepresidenan Moeldoko dan Sekretaris Ditjen P2P Kemenkes Achmad Yurianto. Kemudian perwakilan dari Kepala daerah yakni Gubernur Jawa Barat Ridwan Kamil (RK) dan Gubernur DKI Jakarta Anies Baswedan. Kutipan langsung dari narasumber diatas semuanya bersifat menenangkan dan berusaha menciptakan situasi kondusif di tengah masyarakat untuk menekan kepanikan yang berujung pada panic buying.

Namun dalam artikel yang berjudul "Masker Diborong Usai WNI Terkena Corona, Awas Penimbun Bisa Dibui 5 Tahun!" yang menjelaskan dua warga Depok, Jawa Barat, telah dinyatakan positif terinfeksi Corona. Selanjutnya warga ramai-ramai membeli masker untuk pencegahan. Yang pada akhirnya harga masker melonjak. Namun, perlu diingat bahwa ada sanksi pidana bagi mereka yang menimbun barang. Penekanan pada adanya sangsi pidana bagi penimbun masker, Detik.com berusaha memberikan pandangan lain namun tetap memiliki tema yang sama yakni menciptakan kondusifitas masyarakat, sebagai wujud fungsi kontrol sosial. 
Keempat, struktur retoris, Detik.com memberikan penekanan pada sisi tertentu dengan menggunakan leksikon dan kata-kata tertentu, misal : "Fobia", "panic buying", "efektif", "indikasi penimbunan masker", "berlebihan". "Fobia" dimaksudkan untuk menggambarkan suasana ditengah masyarakat usai Presiden Jokowi mengumumkan 2 orang Indonesia pertama positif Corona. Dikutip dari situs alodokter.com Fobia merupakan perasaan takut yang berlebih terhadap sesuatu yang sebenarnya tidak terlalu membahayakan. ketakutan tersebut timbul ketika dihadapkan pada situasi tertentu, dapat berupa suatu tempat atau ketika bertemu hewan dan benda tertentu. Kata "panic buying" dimaksudkan untuk menggambarkan situasi ditengah masyarakat, Dikutip dari wartaekonomi.co.id bahwa panic buying merupakan situasi yang mana masyarakat luas tiba-tiba memborong bahan pangan, bahan bakar dan lain sebagainya dalam jumlah yang banyak karena kekhawatiran akan situasi yang memburuk terjadi. Panic buying bisa terjadi saat konsumen memborong produk dalam jumlah besar sebagai bentuk antisipasi atau pasca bencana atau antisipasi kenaikan atau penurunan harga yang besar. Seperti yang terjadi di beberapa daerah, masyarakat berbondong-bondong membeli masker, cairan antiseptik dan sembako secara berlebihan.

\section{Hasil Analisis Framing Kompas.Com}

Pertama, struktur sintaksis, peneliti melihat bahwa judul yang dibuat memiliki struktur yang sama dengan Detik.com yang berupaya menciptakan suasana tenang dalam menghadapi wabah baru Covid-19 di tengah masyarakat. Penggunaan summary lead yang lazim digunakan pada media online juga digunakan oleh Kompas.com pada artikel-artikel yang diamati. Kompas.com terlihat lebih bervariatif dalam pemilihan narasumber, tidak hanya dari Pemerintah Pusat maupun Pemerintah daerah namun juga dari stake holder lain. Di mana keseluruhan artikel berita yang dibuat untuk menciptakan kondusifitas di masyarakat. Misal Gubernur Jawa Tengah Ganjar Pranowo, Gubernur Jawa Timur Khofifah Indar Parawansa, Kepala Bagian Penerangan Umum Divisi Humas Polri Kombes Asep Adi Saputra, Ketua Umum Asosiasi Peritel Indonesia (Aprindo) Roy N Mandey, Ketua Umum Palang Merah Indonesia (PMI) Jusuf Kalla (JK).

Kedua, struktur skrip, dari aspek kelengkapan unsur $5 \mathrm{~W}+1 \mathrm{H}$ berita Kompas.com lebih lengkap, penekanan pada unsur What, Why dan How juga dimanfaatkan untuk menunjukkan hubungan antara peristiwa. Misal pada artikel berjudul "Ini Jurus Tangkal Virus Corona ala Ganjar Pranowo" dengan unsur what langkah antisipasi penyebaran virus Corona setelah 2 WNI positif, unsur why yang menjelaskan alasan karena virus Corona telah masuk Indonesia maka perlu adanya antisipasi, dan how sebagai penggambaran dari apa yang hendak disampaikan oleh Ganjar Pranowo terkait langkah-langkah antisipasi yakni dengan cara mencuci tangan dengan air dan menggunakan antiseptik. Mempersiapkan rumah sakit khusus Covid-19.

Ketiga, struktur tematik. Dalam berita Kompas.com teks ditulis dalam 5-7 paragraf dalam satu artikel, sebagian besar paragraf merupakan kutipan atau pernyataan langsung dari narasumber untuk mendukung tema artikel. Namun pemilihan narasumber lebih beragam dilihat dari perwakilan organisasi, diantaranya Gubernur Jawa Tengah Ganjar Pranowo, Gubernur Jawa Timur Khofifah Indar Parawansa, Kepala Bagian Penerangan Umum Divisi 
Humas Polri Kombes Asep Adi Saputra, Ketua Umum Aprindo Roy N Mandey dan Ketua Umum Palang Merah Indonesia (PMI) Jusuf Kalla (JK). Kutipan langsung dari narasumber diatas semuanya bersifat menenangkan dan berusaha menciptakan suasana yang kondusif pada masyarakat untuk menekan kepanikan yang berujung pada panic buying.

Keempat, struktur retoris, Kompas.com memberikan penekanan tertentu dengan menggunakan kata diantaranya. Misal: "galau dan resah", "diburu", "sosialisasi promotif dan preventif kepada masyarakat", "diviralkan" dan "hal-hal yang terjelek".

Penggunaan kata "galau dan resah" dimaksudkan untuk memberi gambaran akibat adanya informasi yang simpang siur terkait virus Corona, Khofifah berupaya melakukan upaya protektif agar masyarakat tetap tenang.

Penggunaan kata "diburu" pada kalimat "masker dan hand sanitizer diburu masyarakat sejak merebaknya virus Corona" ini dimaksudkan untuk menggambarkan situasi ditengah masyarakat yang mengalami kepanikan

Kata "diviralkan" dalam kalimat "warga menjaga kesehatan diri serta keluarga dan tidak cepat terpengaruh oleh kabar maupun berita hoaks yang di viralkan oleh oknum". Dimaksudkan untuk menggembarkan adanya informasi-informasi palsu yang coba dikembangkan oleh oknum-oknum yang tidak bertanggungjawab, agar terjadi kepanikan dan fobia ditengah masyarakat.

\section{Konstruksi Media Online Ditinjau Dari Konsep Psikologis Dan Sosiologis}

Kepiawaian wartawan atau redaksi dalam proses menyusun berita menjadi salah satu aspek yang diteliti dalam penelitian ini. Media online bisa saja membuat pemberitaan hingga puluhan tulisan dari satu peristiwa saja. Desakan untuk memberitakan dengan cepat dapat membuat kredibilitas data menjadi berkurang (dalam Boer, Pratiwi, \& Muna, 2020), Pew Research men-survei beberapa jurnalis, mayoritas mengatakan bahwa internet meningkatkan jumlah informasi yang salah. Pada kenyataannya Arant dan Anderson (dalam Boer et al., 2020) menemukan bahwa separuh editor media online membuat pengakuan perihal sedikitnya waktu yang ada untuk melakukan verifikasi informasi sebelum berita tersebut diunggah (Romli dalam Boer, Pratiwi, \& Muna, 2020).

Pemberitaan setiap media mempunyai sudut pandang dan cara masing- masing dalam menekankan sebuah peristiwa. Kondisi tersebut memiliki hubungan dengan realitas sosial yang diciptakan oleh media. Teori konstruksi sosial media massa dari Burhan Bungin (Bungin, 2000) melihat tentang bagaimana realitas sosial yang dibentuk oleh media massa dapat dipengaruhi oleh faktor internal dan eksternal yang pada akhirnya menciptakan sebuah opini publik dalam melihat situasi munculnya Covid-19 untuk pertama kalinya di Indonesia. Media membentuk realitas yang berasal dari beragam peristiwa yang terjadi sehingga menjadi sebuah cerita atau wacana yang memiliki makna. Pada dasarnya penyusunan berita di media adalah konstruksi realitas- realitas hingga terbentuk sebuah wacana yang bermakna. Sehingga dapat dikatakan bahwa seluruh isi media tiada lain merupakan realitas yang telah dikonstruksikan (constructed reality) dalam kerangka wacana yang berarti. Bahasa merupakan unsur utama dalam proses konstruksi realitas. Bahasa merupakan perangkat 
konseptualisasi dan narasi. Kemudian, penggunaan bahasa tertentu menentukan format narasi tertentu pula. (Hamad dalam Suryawati, 2019).

Terkait pemberitaan mengenai perkembangan Covid-19 ini, media online ramai-ramai menunjukkan kecepatannya dalam menyampaikan informasi terbaru tentang kebijakan pemerintah dalam menanggulangi pandemi dan update terkini jumlah harian orang yang terinfeksi Covid-19. Makin banyak platform media yang memberitakan perkembangan informasi kasus Covid-19 ini baik dari radio, televisi, surat kabar, Youtube, Facebook, Twitter hingga beberapa Media online. Kecanggihan teknologi turut memudahkan masyarakat untuk mengakses informasi, hanya dengan sekali sentuh pada layar smartphone mereka. bagi mereka yang masih awam untuk menggunakan telepon pintar maka dapat mengakses televisi, radio dan surat kabar untuk melihat informasi atau berita. (Handariastuti, Abidin Achmad, \& Bramayudha, 2020)

Masyarakat beranggapan bahwa apa yang tersedia merupakan realitas yang sebenarnya dengan mengedepankan obyektivitas. Akan tetapi pada setiap pemberitaan selalu terdapat subjektivitas dari wartawan. sehingga seringkali fakta atau kebenaran sesungguhnya tidak sesuai dengan berita yang disajikan. Akhirnya, realitas sosial dianggap sebagai "fakta" terlepas benar atau tidaknya konten berita tersebut. Karena diyakini bahwa pesan-pesan media dapat mempengaruhi individu dalam membentuk opini publik (Adhiarso, Utari, \& Slamet, 2017).

Melalui perangkat analisis framing yang dikemukakan oleh Zhong Dang dan M.Kosicki dengan struktur sintaksis, struktur skrip, struktur tematik dan struktur retoris kita dapat mengetahui pesan-pesan yang ditonjolkan pada pemberitaan mengenai Isu Covid-19 yang muncul pertama kali di Indonesia di Detik.com dan Kompas.com . Dengan penekanan pada pesan-pesan tertentu akan membuat khalayak lebih tertuju pada pesan tersebut. Wartawan mengkonstruksi realitas dari beragam peristiwa yang telah terjadi sehingga menjadikannya sebuah cerita atau wacana yang memiliki makna. Penyusunan berita oleh wartawan pada dasarnya merupakan penyusunan realitas- realitas hingga menciptakan sebuah wacana yang bermakna (Hamad dalam Hayati \& Yoedtadi, 2020)

Bagi Pan dan Koscicki, terdapat dua konsepsi pembingkaian yang saling terkait. Pertama, dilihat dari konsepsi psikologi. Framing atau pembingkaian dalam konsepsi psikologi lebih memberi penekanan pada bagaimana individu memproses informasi dalam dirinya. Pembingkaian berkaitan dengan struktur dan proses kognitif, pada bagiamana individu mengelola sebagian informasi dan ditujukan pada kerangka tertentu. Pembingkaian disini dapat dilihat sebagai penempatan informasi ke dalam konteks yang unik dan menempatkan bagian tertentu dari sebuah isu yang lebih menonjol dalam kognisi seseorang. Bagian-bagian yang dipilih dari sebuah peristiwa tersebut tampak menjadi lebih penting dalam memberikan pengaruh kepada individu untuk membuat keputusan tentang realitas (Eriyanto, 2012).

Misal pada artikel berita Detik.com yang berjudul Menkes: Tak Perlu Fobia, Gerakan Hidup Sehat Cukup Cegah Corona yang ingin menjelaskan pernyataan dari Menteri Kesehatan (Menkes) Terawan Agus Putranto soal pola hidup sehat bahwa kita harus menyesuaikan gerakan masyarakat hidup sehat itu sudah sangat cukup untuk mencegah virus 
corona ini merebak. Selama itu terus digaungkan dengan baik cukup untuk mencegahnya. Pemilihan judul serta penekanan pada kutipan seperti ini dapat mempengaruhi kognisi seseorang, agar tidak memunculkan situasi yang tidak diinginkan. Kita tahu bahwa setelah Presiden Joko Widodo mengumumkan dua WNI terinfeksi virus tersebut pada tanggal 2 Maret 2020 yang menjadikan situasi panik di masyarakat. Warga berbondong-bondong memborong masker dan hans sanitizer untuk pencegahan. Harga masker pun melonjak.

Kemudian pada artikel Kompas.com tanggal 2 Maret 2020 dengan judul “ Ini Jurus Tangkal Virus Corona ala Ganjar Pranowo” ingin menonjolkan bagaimana langkah-langkah dari Gubernur Jawa Tengah Ganjar Pranowo dalam menghadapi munculnya temuan baru kasus Covid-19 di Indonesia. Penekanan ini dapat mempengaruhi proses kognitif, bagaimana seseorang mengelola sejumlah informasi dan ditujukan pada skema tertentu.

Lebih lanjut dalam kajian psikologi komunikasi, persuasi menjadi bagian penting ketika kita membahas terkait pembentukan perilaku individu. Persuasi merupakan wujud intervensi pengaruh yang dapat berbentuk apa saja baik tentang sikap, maksud, keyakinan dan motivasi. Dalam pandangan psikologi, persuasif adaalah proses yang memiliki tujuan untuk merubah perilaku dan sikap individu baik secara personal ataupun kelompok terhadap tema, isu, peristiwa dan atau obyek lainnya yang memiliki sifat abstrak seperti ideal (Nida, 2014). Maka bentuk realitas ideal ini yang ingin dituju oleh media massa.

Jika dalam sudut pandang psikologis lebih menitikberatkan pada proses internal individu, yang mana individu secara kognitif memberi makna sebuah peristiwa dalam sudut pandang tertentu, maka pandangan sosiologis lebih menitikberatkan pada bagaimana konstruksi atas realitas. Pembingkaian dipahami pada proses bagaimana seseorang mengelompokkan, mengorganisasikan dan memaknai pengalaman sosialnya untuk memahami dirinya dan realitas di luar dirinya. Pembingkaian disini memiliki fungsi melihat sebuah realitas dapat teridentifikasi, dan dimengerti karena telah dilabeli oleh label tertentu.

Pada artikel Detik.com yang terbit tanggal 2 Maret 2020 dengan judul "Ridwan Kamil: Jangan Panik Beli Masker-Sembako, Supply Demand Kita Aman” yang menghimbau warga agar tidak menyikapi dua warga negara Indonesia (WNI) positif virus Corona dengan panik membeli masker hingga sembako. Berita ini bertujuan agar individu secara kognitif menafsirkan suatu peristiwa dalam cara pandang tertentu, bagaimana lingkungan sosial dikonstruksi seseorang. Dimaksudkan untuk memberikan ketenangan kepada masyarakat bahwa orang yang sakit lebih membutuhkan masker daripada orang sehat, karena peristiwa panik dengan membeli masker dan kebutuhan yang berlebihan dikhawatirkan stok akan menipis dan harga naik. Serta berita yang berjudul "Masker Diborong Usai WNI Terkena Corona, Awas Penimbun Bisa Dibui 5 Tahun!” dengan penekanan pada struktur retoris menggunakan kata "dibui" pada judul dimaksudkan untuk memberi penegasan bahwa barangsiapa yang berusaha menimbun masker demi meraup keuntungan, sanksi pidana telah menanti. Karena dalam situasi pandemi Covid-19, dilarang menimbun masker. Terlebih jika makin jarang. Barangsiapa yang berusaha menimbun masker untuk meraup keuntungan, sanksi pidana telah menanti. Hal ini diatur dalam UU No 7 Tahun 2014 Pasal 107 tentang Perdagangan. 
Sementara itu Kompas.com juga ingin menunjukkan hal yang sama melalui artikel berita yang berjudul "Asosiasi Peritel Minta Masyarakat Tak Lakukan Aksi Borong Barang karena Ada Virus Corona" meminta masyarakat tidak lakukan aksi panic buying atau memborong barang belanjaan dengan adanya penderita Covid-19 di Jakarta. Karena anggota Asosiasi Peritel Indonesia selalu berkomitmen untuk memenuhi kebutuhan pangan ataupun non pangan bagi masyarakat di seluruh wilayah Indonesia, perbuatan yang berlebihan semestinya dihindari karena dapat menimbulkan kepanikan atau fobia baru yang tak perlu terjadi.

Mengambil proposisi utama dari Teori Tanggung Jawab Sosial, pertama, media bertanggungjawab terhadap masyarakat, sedangkan kepemilikan media merupakan kepercataan publik. Kedua, media harus berimbang, jujur, obyektif dan relevan. Ketiga, media harus independen dan bebas mengatur diri sendiri. Keempat, kode etik yang telah disepakati harus dimiliki oleh media dan harus profesional. kelima, dalam situasi tertentu, pemerintah bisa saja turut serta untuk campur tangan demi kepentingan publik (McQuail, 2011). Menurut peneliti apa yang disampaikan Detik.com dan Kompas.com telah memenuhi fungsi media massa sebagai kontrol sosial dan memiliki tanggungjawab sosial, terutama saat situasi kepanikan yang dialami oleh sebagian besar masyarakat Indonesia setelah Presiden Jokowi mengumumkan dua WNI terkonfirmasi positif Covid-19. Peran media massa diharapkan dapat membantu masyarakat untuk bersikap tenang saat pandemi melalui pemberitaan-pemberitaan yang konstruktif.

Pemilihan berita dalam rapat redaksi dapat menjadi semakin ketat. Memang hal tersebut dibutuhkan, terlebih jika terdapat banyaknya peristiwa yang terjadi pada waktu tertentu. Misal dalam sehari, sebuah peristiwa dapat terjadi dalam jumlah ratusan hingga ribuan, kondisi seperti inilah yang menyulitkan media untuk dapat menyajikan keseluruhan peristiwa. Media harus memilih topik berita yang hendak dipublikasi dan dianggap penting, memiliki nilai jual, nilai berita dan selaras dengan visi misinya. Komparasi faktor internal dan eksternal pada organisasi media dapat mempengaruhi berita yang disajikan oleh media kepada khalayak ( Stephen Reese dalam Andhita, 2021). Pemilihan berita dalam konteks menjalankan fungsi kontrol sosial memang selayaknya ditunjukkan dalam kondisi seperti ini, sehingga terdapat muatan pesan yang bisa menunjukkan sikap media.

Tak dapat dipungkiri bahwa pemberitaan yang bernada provokatif di media massa memiliki ketertarikan kuat terhadap perhatian masyarakat. Melalui media sosial dan media massa, menjadi tempat bagi masyarakat untuk menyampaikan opini publik yang menunjukkan empati atau human interest terhadap isu- isu yang berkembang di masyarakat. Karena adanya internet masyarakat dapat menyalurkan pendapatnya melalui media sosial baik Facebook, Instagram, Twitter, Line dan lain sebagainya (Adhiarso et al., 2017).

\section{SIMPULAN}

Pembingkaian berita yang dilakukan Detik.com dan Kompas.com dalam menanggapi situasi kepanikan di tengah masyarakat setelah Presiden Jokowi mengumumkan dua WNI pertama yang positif Covid-19 di Indonesia menunjukkan fungsi media sebagai kontrol sosial. Ditemukan kesamaan pembingkaian dalam menghadapi situasi kepanikan yang 
dialami masyarakat Indonesia. Ditinjau dari struktur sintaksis, bahwa judul yang dibuat oleh Detik.com dan Kompas.com berupaya menghadirkan berita yang dapat menciptakan rasa ketenangan di tengah masyarakat. Penyampaian fakta dari kutipan-kutipan yang ditulis pun juga sejalan dengan judul yang dibuat, ke tokoh penting yang memberikan pernyataanpernyataan yang bersifat menenangkan. Detik.com lebih condong ke pejabat publik, sementara Kompas.com terlihat lebih bervariatif dalam pemilihan narasumber, tidak hanya dari Pemerintah Pusat maupun Pemerintah daerah namun juga dari stakeholder lain. Penekanan pada unsur-unsur What, Why dan How yang dimanfaatkan untuk menghubungkan antar peristiwa pada masing-masing berita juga terlihat.

Secara garis besar pembingkaian berita yang dilakukan oleh kedua media online ini memiliki tema yang sama dalam menginformasikan upaya-upaya menghadapi pandemi dengan tenang, menggerakkan pola hidup sehat, tidak panic buying dan mengantisipasi kemungkinan terburuk sebagai bagian dari fungsi kontrol sosial dan tanggungjawab sosial media massa. Terlihat pada struktur tematik yangmana berita ditulis dalam 5 hingga 9 paragraf dalam satu artikel, sebagian besar paragraf merupakan kutipan atau pernyataan langsung dari narasumber untuk mendukung tema berita. Selain itu, untuk mengetahui cara menekankan fakta dalam struktur retoris Detik.com memberikan penekanan pada sisi tertentu dengan menggunakan kata "fobia", "panic buying", "indikasi penimbunan masker", "berlebihan". Sementara Kompas.com memberikan penekanan tertentu dengan menggunakan kata "galau dan resah" "diburu", "sosialisasi promotif dan preventif kepada masyarakat", dan "diviralkan". Pilihan kata tersebut menunjukkan pemaknaan wartawan terhadap realitas yang terjadi di masyarakat.

\section{UCAPAN TERIMAKASIH}

Penulis mengucapkan syukur dan terimakasih kehadirat Allah SWT, Rasulullah SAW dan para sahabatnya, keluarga, Civitas akademika Universitas Islam Sultan Agung Semarang yang telah memberikan sumbangsih untuk menyelesaikan artikel ini. Terimakasih yang sebesar-besarnya bagi seluruh pihak di Jurnal Avant Garde yang telah memberi kesempatan untuk menyajikan artikel ini, dan kepada reviewer yang telah banyak memberi masukan untuk memperbaiki artikel ini. Semoga artikel ini dapat bermanfaat bagi pembaca agar lebih memahami bagaimana konstruksi berita terkait Covid-19.

\section{DAFTAR PUSTAKA}

Adhiarsi, D.S., Utari, P., \& Slamet, Y/ (2-17). Pemberitaan Hoax di Media Online Ditinjau dari Konstruksi Berita dan Respon Netizen. Jurnal Ilmu Komunikasi, 15(3), 215-225.

Alexa.com. (2020). Top Sites in Indonesia. Retrieved from https://www.alexa.com/topsites/countries/ID

Andhita, P. R. (2021). Hierarki Pengaruh Dalam Pemberitaan Gibran Sebagai Calon Kandidat Walikota Surakarta Di Solopos. com. Avant Garde, 9(1), 35-48.

Boer, K. M., Pratiwi, M. R., \& Muna, N. (2020). Analisis Framing Pemberitaan Generasi Milenial dan Pemerintah Terkait Covid-19 di Media Online. Communicatus: Jurnal Ilmu Komunikasi, 4(1), 85-104. https://doi.org/10.15575/cjik.v4i1.8277 
Bungin, B. (2000). Konstruksi Sosial Media Massa: Makna Realitas Sosial Iklan Televisi dalam Masyarakat Kapitalistik. UNIVERSITAS AIRLANGGA.

Handariastuti, R., Abidin Achmad, Z., \& Bramayudha, A. (2020). Analisis Framing Berita Pemberhentian PSBB Surabaya Raya di Media Online kompas.com dan suarasurabaya.net. Jurnal Ilmu Komunikasi, 10(2), 156-176. https://doi.org/10.15642/jik.2020.10.2.156-176

Hayati, H. N., \& Yoedtadi, M. G. (2020). Konstruksi Berita Covid-19 di Kompas. com dan Tribunnews. com. Koneksi, 4(2), 243-250.

Hutami, M. F., \& Sjafirah, N. A. (2018). Framing Media Online Tribunnews. Com Terhadap Sosok Perempuan Dalam Berita Video Pornografi Depok. Jurnal Kajian Jurnalisme, 2(1), 25-43.

Informasi, Komisi. (2018). UU NOMOR 40 Tahun 1999 Tentang Pers. Retrieved January 2, 2021, from https://komisiinformasi.go.id/?p=1840

Mardatila, A. (2020). Sebelum COVID-19, Inilah Sejarah Virus Corona yang Menginfeksi Manusia. Retrieved from merdeka.com website: https://www.merdeka.com/jateng/sebelum-covid-19inilah-sejarah-virus-corona-yang-menginfeksi-manusia-kln.html

McQuail, D. (2011). Teori komunikasi massa. Salemba Humanika.

Mulyana, D. R. D. (2002). ANALISIS FRAMING Konstruksi, Ideologi, dan Politik Media. Lkis Pelangi Aksara.

Nida, F. L. K. (2014). Persuasi dalam media komunikasi massa. Jurnal Komunikasi Penyiaran Islam “AT-TABSYIR, 2(2), 77-95.

Penanganan Covid-19, S. T. (2020). Data jumlah sebaran kasus Covid-19 per tanggal 28 Maret 2020. Retrieved from www.covid19.go.id

Putri, Z. (2020). Kominfo Temukan 1.125 Hoaks di Medsos Terkait Corona. Retrieved from https://news.detik.com/berita/d-5218475/kominfo-temukan-1197-hoax-terkait-isu-corona-dimedsos?_ga=2.233644190.1682897404.1610591143 370010588.1608098520

Rizki, S., \& Junaedi, F. (2021). Konstruksi Berita Perkosaan Reynhard Sinaga di Tirto dan Tribunnews. Jurnal Interaksi: Jurnal Ilmu Komunikasi, 5(1), 62-77.

Setiawan, A. (2020). Media Online Perlu Berbenah Diri. Retrieved January 2, 2021, from https://dewanpers.or.id/publikasi/opini_detail/173/Media_Online_Perlu_Berbenah_Diri

Suryawati, I. (2019). Strategi Ketahanan Pangan Indonesia dalam Konstruksi Media (Analisis Framing Pada Berita Tirto. Id). Jurnal KOMUNIKATIF Vol, 8(1), 74. 